\title{
Playing to the Regionality of Pharmacies as a Strength in the Search for Skilled Workers
}

\section{A. Changaee (Ali Changaee), E. Kalavsky (Erich Kalavsky)}

Pharmacist, Triangulum-Apotheke, Gelnhausen, DE.

\section{E-mail address:}

change48@gmx.de

\section{Reprint address:}

Ali Changaee

Pharmacist, Triangulum-Apotheke

Hailerer Str. 16,

63571 Gelnhausen

Germany

Source: Clinical Social Work and Health Intervention

Volume: 12

Issue: 3

Pages: $15-18$

Cited references: 11

\section{Reviewers:}

Roberto Cauda

Institute of Infectious Diseases, Catholic University of the Sacred Heart, Rome, IT

Jirina Kafkova

MSF, Freetown, SL

\section{Keywords:}

Regionality. Pharmacies. Shortage of Skilled Workers.

\section{Publisher:}

International Society of Applied Preventive Medicine i-gap

CSWHI 2021; 12(3): 15 - 18; DOI: 10.22359/cswhi_12_3_02 (C) Clinical Social Work and Health Intervention

\section{Abstract:}

The shortage of skilled workers is omnipresent today. In order to be able to fill vacancies with qualified staff, a pharmacy that only operates within a limited regional radius can use this regionality as a strength. The effect can then be used both regionally and supra-regionally by developing strategies IN or WITH the region.

\section{Introduction}

Pharmacies represent an important pillar of the German health care system by ensuring a nationwide supply of medicines and medical pro- ducts. This supply network currently consists of 19,075 individual pharmacies, although this number has been declining since 2009. ${ }^{1}$ In fact, the number of closures has been increasing every

${ }^{1}$ Vgl. ABDA, 2020, p.13. 
year since then, so that regional undersupply may be imminent if this trend is not halted. However, nationwide supply is still guaranteed. ${ }^{2}$

In addition to the increasing competition from online pharmacies, the shortage of skilled workers poses major problems for the sector. On the one hand, existing pharmacies cannot find successors, on the other hand, the shortage of rural doctors is causing a drop in turnover in rural regions, so that village pharmacies can no longer operate profitably and have to close down. ${ }^{3}$

In addition to the increasing competition from online pharmacies, the shortage of skilled workers poses major problems for the sector. On the one hand, existing pharmacies cannot find successors, on the other hand, the shortage of rural doctors is causing a drop in turnover in rural regions, so that village pharmacies can no longer operate profitably and have to close down. ${ }^{4}$ Especially for pharmacies that can only operate regionally, although there is freedom of establishment ${ }^{5}$, It can be difficult to fill vacancies, because the shortage of skilled workers is particularly noticeable in rural regions. ${ }^{6}$

In order to be able to guarantee a nationwide supply of medicines and advice locally in the future, it is necessary to develop strategies to attract skilled workers to the region and to retain them there. Pharmacies have a decisive advantage over other businesses: They are small. Once they are there, small businesses can retain their skilled workers better than large companies. ${ }^{7}$ This is primarily due to the better working atmosphere, which can be described as more of a family atmosphere in pharmacies that employ an average of 9 employees. ${ }^{8}$

Individual pharmacies operate within a limited regional radius. The respective region can be played out as a strength when it comes to finding new skilled workers. Demographic change is a driving force behind the ever-growing shortage of skilled workers, but the reasons are complex. Some of the reasons for a company's lack of attractiveness lie in the company itself, others in its environment, i.e. also in the region in which the company is located. ${ }^{9}$ Now, a pharmacy is never independent of its region, as it has to serve a nationwide supply network. A holistic concept for the human resource management of a regionally operating small business, such as a pharmacy, should therefore always include the region. This can be done in different ways.

\section{Human resource management in the region}

In order to find new staff and retain existing employees in the long term, the attractiveness of a company is crucial. An important building block for increasing the attractiveness of the employer is a better placement of the company in the region. The more attractive a company is, the more attention it gets from potential applicants. This is where classic methods of employer branding come into play, which can be implemented at the regional level ${ }^{10}$ :

\section{1) Cooperation with educational institutions}

Pharmacies can increasingly cooperate with local secondary schools and thus, for example, offer student internships. They are a simple but effective tool to present pharmacy professions to students in a positive way. These positive experiences can arouse the interest of the pupils to become enthusiastic about such a profession. In this way, such internships represent an opportunity to combat the shortage of skilled workers in a region in the long term. ${ }^{11}$

\section{2) Corporate Social Responsibility}

In this concept, the company becomes a 'cit-

\footnotetext{
${ }^{2} \mathrm{Vgl}$. ABDA ,2020, p. 15.

${ }^{3}$ Vgl. Behne et al., 2020, p. 5.

${ }^{4} \mathrm{Vgl}$. Arenberg, 2018, p. 1f.

${ }^{5} \mathrm{Vgl}$. ApBtrO, Stand 2018.

${ }^{6} \mathrm{Vgl}$. Dettman et al., 2019, p. 26.

${ }^{7} \mathrm{Vgl}$. Savov, 2020.

${ }^{8} \mathrm{Vgl}$. ABDA, 2020, p. 20.

${ }^{9}$ Kanning, 2017, p. 16.

${ }^{10}$ Schuhmacher \& Geschwill, 2017, p. 37.

${ }^{11}$ Vgl. Neth, 2018.
} 
izen' of society and assumes a certain social responsibility by acting with the aim of improving social problems. ${ }^{12}$ A pharmacy can show social commitment in many different ways. It can organise self-help groups or contribute to general health education. ${ }^{13}$ Pharmacies can support social projects of various kinds through donations or sponsoring. In principle, of course, this can apply equally to regional and supra-regional projects, but here, with a little skill, the effect on the local community can bring a decisive advantage. This does not necessarily have to be about health issues, rather it is about the aspect of benefit and the message that is transported through it. Social commitment indicates a high level of social competence and a fundamentally positive attitude towards people and always has a positive effect on the image of a company. ${ }^{14}$

\section{3) Health networks and competence centres}

Cooperative networking of pharmacies with other local actors in the health sector, such as doctors, nursing services or clinics, not only ensures the best possible health care for the local population, but also represents an important tool against the local shortage of skilled workers, as the professions concerned gain in value and attractiveness. ${ }^{15}$

All these measures have the best possible effect on the regional image of the pharmacy when they are reported in the media. Publicity can act as a door opener for skilled workers, as a positive media presence of a company increases a candidate's willingness to apply to that company. For this reason, it is always advisable to be in close contact with local media and to ensure that you are regularly mentioned there. ${ }^{16}$

Besides simply increasing the attractiveness and media presence of the company at the local level, a specific orientation of the company's branding towards the region can also be a powerful marketing tool. Even in times of globalisation, people identify primarily with 'their' region.
A regional identification with the company can, for example, take place through the name or the additional logo of a pharmacy, in addition to the generally known 'pharmacy A'. The same can be achieved with the name of the pharmacy. Especially new pharmacies or pharmacies under new ownership can create a regional association here. This creates associations both with the customer and with (potential) employees, which promote an emotional bond and loyalty. ${ }^{17}$ The company stands out from the crowd and can then fulfil the set expectations through other features that are positive but not unique. This measure should therefore also be seen more as a door opener, but not as a self-starter.

\section{Personnel management with the region}

If the pharmacy is well positioned in the region, it is possible to transfer its own branding with the region to the outside world in order to recruit new professionals there. Here, a company can never act alone, but is dependent on a network of various regional companies and the municipality. The key word here is 'place branding'. This term describes the collective efforts of various actors in a region to provide it with a certain image in order to increase its attractiveness for companies, skilled workers, tourism and the citizens themselves. Branding increases the reputation of the entire region and can have a positive impact on economic growth. Appropriate campaigns require actors from politics, industry or the service sector to work together to promote place branding. Every company in a region can thus contribute to the joint effort as part of this marketing community and benefit from the positive image of the region. ${ }^{18}$

In close cooperation with the municipality and or other companies in the region, conditions can also be created that make it easier for new skilled workers, trainees or interns from outside

\footnotetext{
${ }^{12}$ Vgl. Stoll \& Herrmann, 2020, p. 15.

${ }^{13} \mathrm{Vgl}$. ABDA $\rightarrow$ About us $\rightarrow$ Social engagement.

${ }^{14} \mathrm{Vgl}$. Kanning, 2017, S. 105 \& 152 (Tab. 9.5).

${ }^{15} \mathrm{Vgl}$. Munshi et al., 2017, p. 17.

${ }^{16}$ Vgl. Kanning, 2017, p. 178.

${ }^{17}$ Vgl. Kanning, 2017, p. 138.

${ }^{18} \mathrm{Vgl}$. Tauber, 2009.
} 
to gain a foothold in the region. This includes, for example

- the uncomplicated provision of accommodation

- Bonus booklets to get to know the region

- integration into the local social community

Ultimately, it is not only the working atmosphere that is decisive for well-being, but also life in the employer's region. Particularly when skilled workers have been recruited from further away, the employer can play a significant role in making people feel at home outside of work.

\section{References}

1. ABDA - BUNDESVEREINIGUNG (2020) The pharmacy - figures, data, facts 2020.

2. ARENBERG P (2018) Age diversity in organisations as a resource for successful adaptation to demographic change. IN: Demographic Change. Moving towards an agefriendly working world. Published by SRH Fernhochschule. S. 1 - 12.

3. BEHNE A, FITTE C, TEUTEBERG F (2020) Customer survey in pharmacies 2020 as part of the project Pharmacy 2.0 at the University of Osnabrück.

4. DETTMAN E, FACKLER D, MÜLLER S, NEUSCHÄFFER G, SLAVTCHEV V, LEBER U, SCHWENGLER B (2019) IAB Research Report - Shortage of skilled workers in Germany -differences across establishments and possible explanatory factors: results from the IAB Establishment Panel 2018. ISSN 2195-2655.

5. KANNING UP (2017) Personnel marketing, employer branding and employee retention Research findings and practical tips from personnel psychology. Springer. ISBN 9783-662-50374-4.

6. MUNSHI S, HEINZE O, SZECSENYI J, BERGH B (2017) Intelligent networking in the Rhine-Neckar health region. IN: Pfannstiel MA, Focke A, Mehlich H (eds.) (2017) Management of Health Regions II Regional Networking Strategies and Solution Approaches to Improve Health Care. Springer Gabler

7. NETH C (2018) Student internships as an opportunity to combat staff shortages. PTA today online 24.09.2018.

8. SAVOV R, LANCARIC D, KOZAKOVA J (2020) Size of the Company as the Main De- terminant of Talent Management in Slovakia. J. Risk Financial Manag. 2020, 13(3), 50; https://doi.org/10.3390/jrfm13030050.

9. SCHUHMACHER F, GESCHWILL R (2017) Employer Branding, Human Resources Management for Corporate Management. 2nd, revised and expanded edition. Springer Gabler

10. STOLL B, HERRMANN H (2020) What corporate social responsibility is... depends on its framing. IN: Stoll, B. \& Herrmann, H. (Eds.) Corporate Social Responibility - Impulses from and for the Profit and Social Economy.

11. TAUBER AK (2009) Grundlagen und Ansatzpunkte des Place Branding, Universität Kassel, ISBN 9783640420452. 